\title{
Lekkasje ved stentgraft i aorta
}

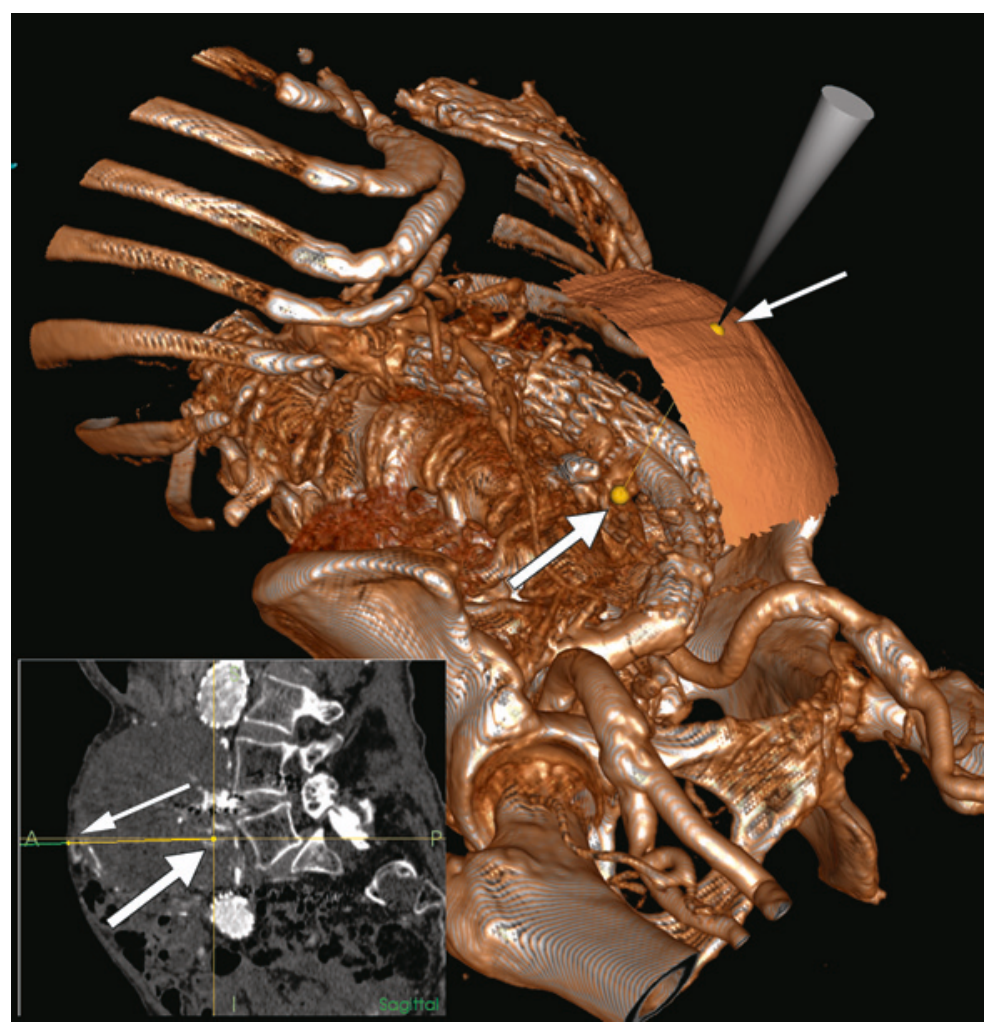

Hos en kvinne behandlet med stentgraft for et abdominalt aortaaneurisme oppsto det via kollateraler retrograd blodstrøm gjennom to lumbalarterier og inn mellom aortaveggen og stentgraftet. CT-kontroller viste økende størrelse av aneurismet med bestående rupturfare. Endovaskulære forsøk på embolisering av blodårene som normalt forsyner kollateralnettverket var mislykket. Man ville derfor forsøke direkte embolisering med et mikrokateter via en perkutant anlagt nål med tuppen nær lumbalarteriene. Vanligvis plasseres nålen under CT-veiledning, men det innebærer en transportetappe til gjennomlysningsstuen der selve emboliseringen finner sted, og nålen kan ikke reposisjoneres.

Nasjonalt kompetansesenter for ultralyd og bildeveiledet behandling har utviklet et navigasjonssystem (1) som kontinuerlig viser posisjonen til forskjellige instrumenter $i$ et 3D-bilde. I en gjennomlysningsstue med integrert 3D-avbildningsutstyr kunne det ved hjelp av navigasjonssystemet utføres perkutan embolisering uten å måtte flytte pasienten. Stor figur viser et 3D-bilde av pasienten med nåletuppens plassering på hudoverflaten (tynn pil) og retning mot en av lumbalarteriene (tykk pil). Slik kan nålen plasseres optimalt og posisjonen kontrolleres underveis med mulighet for flere innstikk basert på samme bildeopptak. Liten figur viser samme oppsett i sagittalplanet. Mikrokateteret ble anlagt via nålen og lumbalarteriene embolisert med Onyx-injeksjoner. Kontroll halvannet år senere viste ingen lekkasje og uendret størrelse på aneurismet. Metoden er eksperimentell og del av et pågående forskningsprosjekt.

Pasienten har gitt samtykke til at artikkelen blir publisert.

\section{Frode Manstad-Hulaas}

frode.manstad.hulaas@ntnu.no

Avdeling for radiologi

St. Olavs hospital

og

Institutt for sirkulasjon og bildedignostikk

Norges teknisk-naturvitenskapelige universitet

Geir Arne Tangen

SINTEF

og

Institutt for sirkulasjon og bildediagnostikk

Norges teknisk-naturvitenskapelige universitet
Frode Manstad-Hulaas (f. 1973) er lege i spesialisering, med ph.d. i medisinsk teknologi. Han er med i Nasjonalt kompetansesenter for ultralyd og bildeveiledet behandling.

Forfatter har fylt ut ICMJE-skjemaet og oppgir ingen interessekonflikter.

Geir Arne Tangen (f. 1968) er forsker (MSc) og stipendiat og er med i Nasjonalt kompetansesenter for ultralyd og bildeveiledet behandling. Forfatter har fylt ut ICMJE-skjemaet og oppgir ingen interessekonflikter.

Litteratur

1. Manstad-Hulaas F, Tangen GA, Dahl T et al. Three-dimensional electromagnetic navigation vs. fluoroscopy for endovascular aneurysm repair: a prospective feasibility study in patients. J Endovasc Ther 2012; 19: 70-8.

Mottatt 31.5. 2013, første revisjon innsendt 4.10. 2013, godkjent 13.11. 2013. Redaktør: Hanne Støre Valeur.

Engelsk oversettelse på www.tidsskriftet.no 